\title{
Molecular Docking Senyawa Ekstrak Etanol Daun Kenikir (Cosmos caudatus) Sebagai Inhibitor IL-6 dalam Respon Inflamasi
}

\author{
Niky Murdaya $^{1}$, Adnan Aly Al Shofwan ${ }^{1}$, Ratu Wifaira Azzahra ${ }^{1}$, Savira Dwi Utami ${ }^{1}$, Erlangga \\ Ramadan $^{1}$, Cecep Suhandi ${ }^{2}$ dan Muchtaridi Muchtaridi ${ }^{2}$ \\ ${ }^{1}$ Program Studi Sarjana Farmasi, Fakultas Farmasi, Universitas Padjadjaran \\ ${ }^{2}$ Departemen Analisis Farmasi dan Kimia Medisinal, Fakultas Farmasi, Universitas Padjadjaran
}

Reception date of the manuscript: 8 Februari 2020

Acceptance date of the manuscript: 14 Agustus 2021

Publication date: 31 Desember 2021

\begin{abstract}
Inflammation is the body's natural reaction to protect itself from pathogens that cause disease. Interleukin-6 (IL-6) acts as a pro-inflammatory and anti-inflammatory cytokine released by $\mathrm{T}$ cells and macrophages to stimulate an immune response when an infection occurs. In this study, an in silico study of the ethanolic extract of kenikir (Cosmos caudatus) leaves as an anti-inflammatory based on its affinity for Interleukin-6 (IL-6) was carried out using the in silico molecular docking method. This research includes simulations of molecular docking of the ethanol extract of kenikir leaves against the IL-6 receptor (PDB ID: 1ALU) and prediction of pharmacokinetic profiles and toxicity using the Pre-ADMET server. The results showed that four potential compounds were obtained, namely C1 (Kaempferol), C2 (1-Caffeoylquinic acid, C3 (Procyanidin B1), dan C5 (Quercetin-3-O-pentoside). The four compounds have better G and Ki values compared to natural ligands. G value; Ki test compounds, namely (-5.29 Kcal / mol; $133.31 \mathrm{uM}),(-6.02 \mathrm{Kcal} / \mathrm{mol} ; 38.44 \mathrm{uM}),(-5.38 \mathrm{Kcal}$ / mol; 114, $24 \mathrm{uM})$, and (-5.46 Kcal / mol; $99.50 \mathrm{uM})$. PreADMET results of the four compounds have good adsorption power so that they can be considered in the preparation of oral route preparations. The results of the Ames test showed that $\mathrm{C} 1$ and $\mathrm{C} 2$ were mutagenic, while $\mathrm{C} 3$ and $\mathrm{C} 4$ were non-mutagenic.
\end{abstract}

Keywords-IL-6, Inflammation, Cosmos caudatus, Molecular Docking, 1ALU

\begin{abstract}
Abstrak - Inflamasi merupakan reaksi alami tubuh untuk melindungi diri dari patogen menyebab penyakit. Interleukin-6 (IL-6) berperan sebagai sitokin pro-inflamasi dan antiinflamasi yang dikeluarkan oleh sel $\mathrm{T}$ dan makrofag untuk merangsang respon imun saat terjadi infeksi. Pada penelitian ini, dilakukan studi in silico ekstrak etanol daun kenikir (Cosmos caudatus) sebagai anti-inflamasi yang didasarkan pada afinitas terhadap Interleukin-6 (IL-6) dengan menggunakan metode molecular docking secara in silico. Penelitian ini meliputi simulasi penambatan molekuler kandungan senyawa ekstrak etanol daun kenikir terhadap reseptor IL-6 (PDB ID: 1ALU) dan prediksi profil farmakokinetik dan toksisitas menggunakan server Pre-ADMET. Hasil penelitian menunjukkan bahwa diperoleh empat senyawa potensial, yaitu C1 (Kaempferol), C2 (1-Caffeoylquinic acid, C3 (Procyanidin B1), dan C5 (Quercetin-3-O-pentoside).Keempat senyawa tersebut memiliki nilai $\mathrm{G}$ dan Ki yang lebih baik dibandingkan dengan ligan alami. Nilai G; Ki senyawa uji tersebut, yaitu berturut-turut (-5,29 $\mathrm{Kkal} / \mathrm{mol} ; 133,31 \mathrm{uM}),(-6,02 \mathrm{Kkal} / \mathrm{mol} ; 38,44 \mathrm{uM}),(-5,38 \mathrm{Kkal} / \mathrm{mol} ; 114,24 \mathrm{uM})$, dan $(-5,46 \mathrm{Kkal} / \mathrm{mol}$; $99,50 \mathrm{uM})$. Hasil PreADMET keempat senyawa tersebut memiliki daya adsorpsi yang baik sehingga dapat dipertimbangkan dalam pembuatan sediaan rute oral. Hasil ames test menunjukkan bahwa $\mathrm{C} 1$ dan $\mathrm{C} 2$ bersifat mutagenik, sedangkan $\mathrm{C} 3$ dan $\mathrm{C} 4$ non mutagenik.
\end{abstract}

Kata Kunci-IL-6, Inflamasi, Cosmos caudatus, molecular docking, 1ALU

\section{Pendahuluan}

Secara umum, peradangan adalah respon sistem kekebalan tubuh terhadap adanya iritan. Iritan ini bisa berupa patogen seperti bakteri, virus, dan jamur. Iritan yang lain juga dapat disebabkan oleh cedera eksternal seperti goresan atau keru-

Penulis koresponden: Caesar Bagus Reyaldi, Email: caesar1600023082@webmail.uad.ac.id sakan akibat benda asing serta efek bahan kimia atau radiasi (Chen et al., 2017).

Terdapat dua jenis peradangan atau inflamasi, yaitu akut dan kronis. Inflamasi yang umum dikenal masyarakat adalah inflamasi akut. Secara fisik, inflamasi akut ditandai dengan kemerahan, demam, bengkak, dan nyeri di sekitar jaringan dan persendian yang menjadi tempat terjadinya inflamasi berlangsung sebagai respons tubuh, seperti saat seseorang terjatuh. Ketika tubuh terluka, sistem kekebalan tubuh akan melepaskan sel darah putih untuk mengelilingi dan melin- 
dungi area tersebut. Sebaliknya, ketika peradangan menjadi terlalu parah dan bertahan untuk waktu yang lama, sistem kekebalan tubuh akan terus memompa sel darah putih dan pembawa pesan kimiawi yang memperpanjang proses tersebut, yang dikenal sebagai peradangan kronis. Ketika ini terjadi, sel darah putih mungkin akhirnya menyerang jaringan dan organ sehat di dekatnya. Misalnya, jika penderita memiliki kelebihan berat badan dan sel lemak visceral (jenis lemak dalam yang mengelilingi organ) yang berlebih, sistem kekebalan mungkin melihat sel tersebut sebagai ancaman dan menyerangnya dengan sel darah putih. Semakin lama kelebihan berat badan berlangsung, semakin lama tubuh mengalami inflamasi. Penelitian telah menunjukkan bahwa peradangan kronis dikaitkan dengan penyakit jantung, diabetes, kanker, radang sendi, dan penyakit usus seperti penyakit Crohn dan kolitis ulserativa (Harvard Health Publishing, 2020).

Selain itu, peradangan akut terjadi dalam beberapa menit atau jam, biasanya sembuh dalam beberapa hari, memiliki tanda dan gejala klasik, dan memiliki infiltrat seluler yang terutama terdiri dari neutrofil. Eritema yang terlihat pada peradangan akut terjadi akibat peningkatan aliran darah ke area yang terkena akibat adanya vasodilatasi. Peradangan kronis memiliki onset hari yang lambat, durasi bertahun-tahun, tanda dan gejala klasik yang kurang menonjol, dan infiltrat seluler terutama terdiri dari monosit/makrofag dan limfosit. Paparan kronis seperti bahan kimia beracun dan agen lingkungan seperti asap rokok dapat menyebabkan peradangan kronis yang sesuai dengan macam iritan yang telah disampaikan (Stone et al., 2020).

Interleukin-6 (IL-6) diproduksi pada bagian tubuh yang mengalami peradangan dan memiliki peran dalam respons fase akut dan kronis (Gabay, 2006). Mengingat tindakan IL-6 untuk mengembalikan host ke keadaan homeostatis, menunjukan bahwa IL-6 bekerja untuk mengontrol tingkat respons inflamasi jaringan. Pada penyakit kronis, biasanya dicontohkan oleh stressor imun seperti infeksi intraseluler kronis dan tumor. IL-6 tidak hanya berfungsi sebagai pemicu reaksi fase akut tetapi juga berperan dalam memunculkan respons imun seluler ke sel yang mengalami inflamasi dan respons humoral mukosa yang ditujukan untuk melawan infeksi yang mungkin bisa terulang di lain waktu (Kopf et al., 2006). Daun kenikir (Cosmos caudatus) memiliki senyawa dari golongan fenolik dan flavonoid yang bersifat antiinflamasi. Antiinflamasi adalah senyawa yang dapat memperbaiki sel-sel dalam tubuh yang sedang mengalami peradangan atau inflamasi. Senyawa yang terkandung dalam ekstrak etanol daun kenikir tersebut antara lain adalah asam kuinat, katekin, kuersetin, dan kaempferol (Rahman dkk., 2016).

Hasil penelitian dari pengaruh ekstrak etanol daun kenikir terhadap kadar IL-6 pada tikus wistar jantan yang diberi pakan tinggi kolesterol menunjukan bahwa pemberian ekstrak etanol daun kenikir mempengaruhi kadar IL-6 serum tikus dengan diet kolesterol tinggi yang hasilnya lebih rendah daripada tikus yang menerima perlakuan sama tanpa pemberian ekstrak etanol daun kenikir, dimana tikus wistar jantan yang hanya diberi pakan tinggi kolesterol memiliki kadar IL-6 pada serum tikus sebesar 2,17 ng/L. Sedangkan pada tikus yang diberi pakan tinggi kolesterol dan ekstrak etanol daun kenikir, kadar IL-6 pada serum tikus lebih rendah yaitu sebesar 1,31 ng/L (Sarihati dan Dhyanaputri, 2020). Maka dari itu, perlu dilakukan penelitian untuk mengetahui aktivitas ekstrak etanol daun kenikir sebagai antiinflamasi menggunakan metode molecular docking secara in silico. Dengan metode ini dapat diketahui afinitas ikatan ligan uji serta interaksi yang terjadi sehingga dapat diprediksi potensi senyawa dalam ekstrak etanol daun kenikir sebagai antiinflamasi pada tikus wistar jantan.

\section{BAHAN DAN METODE \\ Bahan}

Bahan yang digunakan antara lain reseptor human interleukin-6 (PDB ID: 1ALU) dan struktur 3D dari senyawa ekstrak etanol pada daun kenikir (kaempferol, 1-caffeoylquinic acid, procyanidin B1, kaempferol-7-Oglucoside, quercetin-3-O-pentoside, katekin, quinic acid, mono-galloyl glucose, quercetin-rhamnosyl-galactoside, quercetin-3-glucoside, quercetin), serta senyawa standar kurkumin.

\section{Alat}

Peralatan yang digunakan dalam artikel ini adalah laptop dengan spesifikasi Windows 1064 bit, software Chem3D 16.0, software Chemdraw Pro 12.0, software Biovia Discovery Studio 2021, software Autodocktool 1.5.6, software Autodock 4.2.6, dan situs preadmet.bmdrc.kr.

\section{Metode \\ Proses re-docking}

Proses validasi metode molecular docking dilakukan dengan re-docking ligan alami dengan reseptornya yang bertujuan untuk memastikan parameter docking yang digunakan telah valid sehingga dapat digunakan selanjutnya untuk docking senyawa uji.

Reseptor yang digunakan merupakan struktur dari molekul reseptor human interleukin-6, sebagai target, pada situs database RCSB PDB dengan kode 1ALU dalam format PDB. Reseptor dipreparasi dengan menghapus molekul air, mengoreksi struktur senyawa dan menambahkan muatan Kollman terhadap struktur protein. Reseptor kemudian disimpan sebagai berkas dengan format .pdbqt.

Ligan alami yang akan ditambatkan ulang disiapkan dengan mengekstraksi senyawa dari kompleksnya pada reseptor menggunakan Biovia Discovery Studio. Ligan kemudian dipreparasi dengan mengoreksi struktur ligan dan menambahkan muatan Gasteiger. Ligan kemudian disimpan sebagai berkas dengan format .pdbqt.

Proses re-docking dilakukan dengan menambatkan senyawa ligan terhadap reseptor menggunakan program AutoDock 4.2.6. Parameter grid sebagaimana pada Tabel 1 dan parameter docking diatur pada pengaturan default dan nilai genetic algorithm sebesar 50. Validasi metode docking dinilai dari nilai RMSD yang diperoleh.

\section{docking Senyawa Ekstrak Etanol Daun Kenikir dan Senyawa Standar Kurkumin dengan Reseptor Human Interleukin-6}

Struktur 3D dari senyawa ekstrak etanol daun kenikir dan struktur kurkumin sebagai senyawa standar disiapkan menggunakan software ChemDraw Pro 12.0 serta dioptimasi dengan melakukan proses minimize energy menggunakan software Chem3D 16.0. 
TABEL 1: Hasil VAlidasi Metode molecular docking

\begin{tabular}{cllllll}
\hline $\begin{array}{c}\text { Ligan } \\
\text { Alami }\end{array}$ & $\begin{array}{l}\text { Energi } \\
\text { Ikatan Bebas } \\
(\text { Kkal/mol })\end{array}$ & $\begin{array}{l}\text { RMSD } \\
(\AA)\end{array}$ & $\begin{array}{l}\text { Konstanta } \\
\text { Inhibisi } \\
(\mathrm{uM})\end{array}$ & $\begin{array}{l}\text { Ikatan } \\
\text { Hidrogen }\end{array}$ & $\begin{array}{l}\text { Ukuran } \\
\text { Grid Box }\end{array}$ & $\begin{array}{l}\text { Koordinat } \\
\text { Grid Box }\end{array}$ \\
\hline \multirow{2}{*}{ L-Tartaric acid } & \multirow{2}{*}{$-4,33$} & \multirow{2}{*}{1,410} & \multirow{2}{*}{667,68} & ARG179, ARG182, GLN175 & 40x40x40 & $\begin{array}{l}\mathrm{x}=-7,667 \\
\mathrm{y}=-12,743 \\
\mathrm{z}=0,007\end{array}$ \\
\hline
\end{tabular}

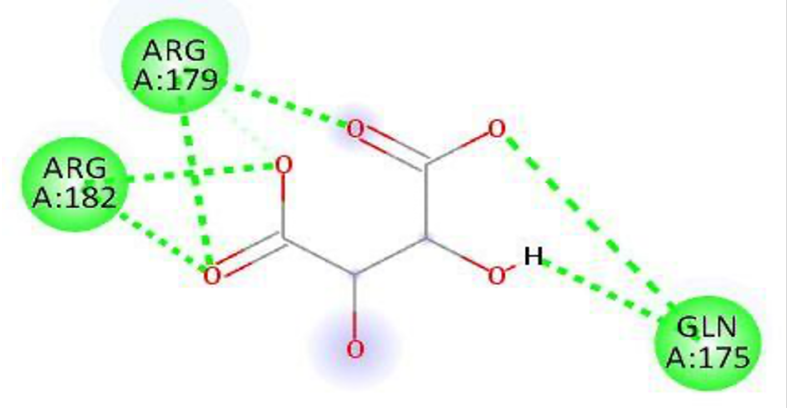

Gambar. 1: Struktur 2D hasil validasi metode molecular docking antara reseptor human interleukin-6 dengan ligan alami L-Tartaric acid. Ikatan Hidrogen ditandai dengan lingkaran berwarna hijau yang berada disekitar struktur ligan alami

Struktur dari Senyawa Ekstrak Etanol Daun Kenikir dan Senyawa Standar Kurkumin yang sebelumnya telah dioptimasi, Selanjutnya masing masing akan di-docking dengan Reseptor Human Interleukin-6. Prosedur untuk docking senyawa uji hampir serupa dengan prosedur validasi metode, namun pada proses preparasi grid pengaturan koordinat interaksinya disesuaikan dengan koordinat interaksi reseptor dengan ligan alami, yaitu koordinat yang digunakan ketika dilakukan validasi metode.

Sehingga dari proses docking didapat hasil dalam bentuk visualisasi 2D dan beberapa informasi seperti nilai energi ikatan, konstanta inhibitor, dan juga ikatan hidrogen yang terjadi antara senyawa dengan reseptor.

\section{Pengujian Pre-ADMET}

Pengujian pre-ADMET dilakukan menggunakan situs preadmet.bmdrc.kr. Untuk pengujian ADME pertama membuka situs tersebut dan pilih bagian ADME, lalu menggambar struktur dari senyawa yang ingin diketahui ADME nya. Selanjutnya untuk pengujian toksisitas masih menggunakan situs preadmet.bmdrc.kr dan pilih bagian toxicity kemudian menggambar kembali struktur senyawa yang ingin diketahui toksisitasnya.

\section{HASIL}

\section{Validasi Metode molecular docking}

Validasi metode molecular docking dilakukan dengan redocking ligan alami dengan reseptornya menggunakan software AutoDock Tools 1.5.6. Ikatan antara ligan dengan reseptornya dapat dikatakan valid jika nilai RMSD yang diperoleh sebesar $\leq 2 \AA$, yang artinya parameter docking yang digunakan telah valid sehingga dapat digunakan selanjutnya untuk docking senyawa uji (Muttaqin, dkk., 2019). Proses validasi ini akan menghasilkan beberapa informasi seperti nilai RMSD, konstanta inhibitor, dan ikatan hidrogen seperti yang ditampilkan pada Gambar 3. dan Tabel 1.

\section{docking Senyawa Ekstrak Etanol Daun Kenikir dan Senyawa Standar Kurkumin dengan Reseptor Human Interleukin-6}

docking dilakukan antara senyawa ekstrak etanol daun kenikir dan senyawa standar kurkumin dengan menggunakan AutodockTools 4.2.6. Pengaturan koordinat interaksi diatur sama dengan koordinat interaksi reseptor dengan ligan alami. Dari hasil docking didapatkan beberapa data seperti energi ikatan dan konstanta inhibisi. Selain itu, dapat diketahui juga ikatan hidrogen yang terjadi antara senyawa dengan reseptor dengan menggunakan software Biovia Discovery Studio 2021. Hasil tersebut ditunjukkan dalam Tabel 2. Setelah itu didapatkan 4 senyawa terbaik dari senyawa ekstrak etanol daun kenikir seperti yang ditunjukkan pada Gambar 2.

\section{Hasil Pengujian Pre-Admet}

Setelah dilakukan proses docking, selanjutnya dilakukan pengujian dengan Pre-admet (Tabel. 3).

\section{Pembahasan}

Senyawa obat baru dikatakan berpotensi apabila memiliki afinitas yang tinggi. Afinitas yaitu kemampuan ligan (senyawa obat) untuk berikatan dengan reseptor. Afinitas liganreseptor sendiri dipengaruhi oleh beberapa faktor, yaitu jumlah ikatan hidrogen, residu asam amino, energi bebas ikatan (G), dan konstanta inhibisi (Ki) (Arwansyah dkk, 2014).

Semakin banyak ikatan hidrogen menandakan ikatan yang terbentuk semakin kuat. Selain jumlah ikatan hidrogen, adanya kesamaan ikatan hidrogen menjadi faktor penting. Apabila ikatan hidrogen yang dihasilkan oleh senyawa uji sama dengan ikatan yang terbentuk antara ligan alami-reseptor, hal tersebut menandakan senyawa uji mampu menghambat aktivitas protein target dengan menggantikan posisi ligan alami (Forlemu, 2016). Berdasarkan hasil docking, ikatan hidrogen yang terbentuk antara ligan alami-reseptor, yaitu ARG179, ARG182, dan GLN175. Senyawa uji yang memiliki kesamaan ikatan hidrogen yaitu C1 (Kaempferol), C2 (1- 
JURNAL FARMASI UDAYANA I pISSN: 2301-7716; eISSN: 2622-4607 I VOL. 10, NO. 2, 2021 https://doi.org/10.24843/JFU.2021.v10.i02.p05

TABel 2: Hasil docking Senyawa Uji dan Senyawa STANDAR DENGan Reseptor

\begin{tabular}{lccc}
\hline Senyawa & $\begin{array}{c}\text { Energi Ikatan Bebas } \\
(\text { Kkal/mol })\end{array}$ & $\begin{array}{c}\text { Konstanta } \\
\text { Inhibisi (uM) }\end{array}$ & Ikatan Hidrogen \\
\hline $\begin{array}{l}\text { Standar } \\
\text { (Kurkumin) }\end{array}$ & $-5,16$ & 166,39 & GLN 175, ARG 182, ARG 179 \\
\hline $\begin{array}{l}\text { C1 } \\
\text { Kaempferol) }\end{array}$ & $-5,29$ & 133,31 & ARG 30, ASP 26, ARG 179 \\
\hline $\begin{array}{l}\text { C2 }(1-\text { Caffeoylquinic acid) } \\
\text { C3 }\end{array}$ & $-6,02$ & 38,44 & ARG 182, ARG 30 \\
\hline $\begin{array}{l}\text { C4 } \\
\text { (Kaempferol-7-O-glucoside) }\end{array}$ & $-5,38$ & 114,24 & ASP 26, GLN 175 \\
\hline $\begin{array}{l}\text { C5 } \\
\text { Quercetin-3-O-pentoside) }\end{array}$ & $-4,29$ & 716,67 & GLN 175, ARG 182 \\
\hline $\begin{array}{l}\text { C6 } \\
\text { (Katekin) }\end{array}$ & $-5,46$ & 99,50 & LEU 178, ARG 182, ARG 179 \\
\hline $\begin{array}{l}\text { C7 } \\
\text { (Monogalloyl glucose) }\end{array}$ & $-4,59$ & 431,97 & ARG 30, GLU 23, LEU 19, LYS 27 \\
\hline $\begin{array}{l}\text { C8 } \\
\text { Quercetin) }\end{array}$ & $-3,70$ & 1,93 & ASP 26, GLU 23 \\
\hline $\begin{array}{l}\text { C9 } \\
\text { Quercetin-3-glucoside) }\end{array}$ & $-4,46$ & 538,73 & SER 22, ARG 30, LYS 27, GLU 23 \\
\hline $\begin{array}{l}\text { C10 } \\
\text { Quercetin-rhamnosyl- galactoside) }\end{array}$ & $-2,29$ & 639,93 & GLU 23, ASP 26, ARG 30, LYS 27 \\
\hline $\begin{array}{l}\text { C11 } \\
\text { Quinic acid) }\end{array}$ & $-2,57$ & 21,11 & ASP 26, LYS 27 \\
\hline & $-4,36$ & ARG 30, LYS 27 \\
\hline
\end{tabular}

(20)

Gambar. 2: Struktur 2D hasil molecular docking antara reseptor human interleukin-6 dengan 4 senyawa terbaik dari senyawa ekstrak etanol daun kenikir. (a) kaempferol, (b) 1-caffeoylquinic acid, (c) procyanidin B1, (d) quercetin-3-O-pentoside 
TABEL 3: Hasil PRE-ADMET

\begin{tabular}{|c|c|c|c|c|c|c|c|c|c|}
\hline \multirow[t]{2}{*}{ Senyawa } & \multicolumn{2}{|l|}{ Absorbsi } & \multicolumn{2}{|c|}{ Distribusi } & \multicolumn{4}{|c|}{ Metabolisme } & \multirow{2}{*}{$\begin{array}{l}\text { Toksisitas } \\
\text { Ames test }\end{array}$} \\
\hline & $\begin{array}{l}\text { HIA } \\
(\%)\end{array}$ & $\begin{array}{l}\text { CaCo-2 } \\
(\mathrm{nm} / \mathrm{sec})\end{array}$ & $\begin{array}{l}\text { PPB } \\
(\%)\end{array}$ & BBB & $\begin{array}{l}\text { Inhibisi } \\
\text { CYP2C19 }\end{array}$ & $\begin{array}{l}\text { Inhibisi } \\
\text { CYP2C9 }\end{array}$ & $\begin{array}{l}\text { Inhibisi } \\
\text { CYP2D6 }\end{array}$ & $\begin{array}{l}\text { Inhibisi } \\
\text { CYP3A4 }\end{array}$ & \\
\hline Ligan alami & 18.451472 & 0.814036 & 27.9 & 0.246 & $\begin{array}{l}\text { Non } \\
\text { Inhibitor }\end{array}$ & Inhibitor & $\begin{array}{l}\text { Non } \\
\text { Inhibitor }\end{array}$ & $\begin{array}{l}\text { Non } \\
\text { Inhibitor }\end{array}$ & Mutagen \\
\hline Senyawa Standar & 91.960459 & 20.9191 & 61.09 & 0.0728 & Inhibitor & Inhibitor & $\begin{array}{l}\text { Non } \\
\text { Inhibitor }\end{array}$ & Inhibitor & $\begin{array}{l}\text { Non } \\
\text { Mutagen }\end{array}$ \\
\hline $\mathrm{C} 1$ & 79.439289 & 9.57744 & 89.6 & 0.286 & Inhibitor & Inhibitor & $\begin{array}{l}\text { Non } \\
\text { Inhibitor }\end{array}$ & Inhibitor & Mutagen \\
\hline $\mathrm{C} 2$ & 20.429530 & 18.2965 & 42.09 & 0.035 & Inhibitor & Inhibitor & $\begin{array}{l}\text { Non } \\
\text { Inhibitor }\end{array}$ & Inhibitor & Mutagen \\
\hline $\mathrm{C} 3$ & 19.510403 & 13.6793 & 100 & 0.064 & Inhibitor & Inhibitor & $\begin{array}{l}\text { Non } \\
\text { Inhibitor }\end{array}$ & Inhibitor & $\begin{array}{l}\text { Non } \\
\text { Mutagen }\end{array}$ \\
\hline $\mathrm{C} 4$ & 22.808860 & 14.1435 & 65.43 & 0.033 & Inhibitor & Inhibitor & $\begin{array}{l}\text { Non } \\
\text { Inhibitor }\end{array}$ & Inhibitor & Mutagen \\
\hline C5 & 22.624249 & 6.60347 & 61.95 & 0.0348 & Inhibitor & Inhibitor & $\begin{array}{l}\text { Non } \\
\text { Inhibitor }\end{array}$ & Inhibitor & $\begin{array}{l}\text { Non } \\
\text { Mutagen }\end{array}$ \\
\hline C6 & 66.707957 & 0.656902 & 100 & 0.428 & Inhibitor & Inhibitor & $\begin{array}{l}\text { Non } \\
\text { Inhibitor }\end{array}$ & Inhibitor & Mutagen \\
\hline $\mathrm{C} 7$ & 12.180835 & 7.06491 & 35.06 & 0.037 & Inhibitor & Inhibitor & $\begin{array}{l}\text { Non } \\
\text { Inhibitor }\end{array}$ & Inhibitor & Mutagen \\
\hline $\mathrm{C} 8$ & 69.174008 & 13.2434 & 97.48 & 0.3736 & Inhibitor & Inhibitor & $\begin{array}{l}\text { Non } \\
\text { Inhibitor }\end{array}$ & Inhibitor & Mutagen \\
\hline C9 & 12.255885 & 9.43679 & 44.41 & 0.0309 & Inhibitor & Inhibitor & $\begin{array}{l}\text { Non } \\
\text { Inhibitor }\end{array}$ & Inhibitor & $\begin{array}{l}\text { Non } \\
\text { Mutagen }\end{array}$ \\
\hline $\mathrm{C} 10$ & 2.861574 & 10.867 & 45.88 & 0.0285 & Inhibitor & Inhibitor & $\begin{array}{l}\text { Non } \\
\text { Inhibitor }\end{array}$ & Inhibitor & $\begin{array}{l}\text { Non } \\
\text { Mutagen }\end{array}$ \\
\hline C11 & 20.286936 & 8.27242 & 6.59 & 0.037 & $\begin{array}{l}\text { Non } \\
\text { Inhibitor }\end{array}$ & Inhibitor & $\begin{array}{l}\text { Non } \\
\text { Inhibitor }\end{array}$ & $\begin{array}{l}\text { Non } \\
\text { Inhibitor }\end{array}$ & Mutagen \\
\hline
\end{tabular}

Caffeoylquinic acid, C3 (Procyanidin B1), C4 (Kaempferol7-O-glucoside), dan C5 (Quercetin-3-O-pentoside).

Selain itu, energi ikatan bebas (G) dan konstanta inhibisi (Ki) juga menjadi parameter kualitas ikatan yang terbentuk. Energi ikatan bebas (G) merupakan energi yang dibutuhkan untuk terbentuknya ikatan tersebut. Semakin rendah nilai $\mathrm{G}$, maka ikatan yang terbentuk semakin spontan. Konstanta inhibisi (Ki) sendiri berbanding terbalik dengan energi torsional. Semakin kecil Ki, maka energi torsional semakin meningkat dan ikatan yang terbentuk pun semakin stabil. Oleh karena itu, G dan Ki menggambarkan spontanitas dan stabilitas ikatan yang terbentuk (Noviardi dan Fachrurrazie, 2015). Senyawa uji yang memiliki nilai G dan Ki lebih kecil dari ligan alami dan senyawa standar (kurkumin), yaitu C1, C2, C3, dan C5. Nilai G; Ki senyawa uji tersebut, yaitu berturut-turut $(-5,29 \mathrm{Kkal} / \mathrm{mol} ; 133,31 \mathrm{uM}),(-6,02$ $\mathrm{Kkal} / \mathrm{mol} ; 38,44 \mathrm{uM}),(-5,38 \mathrm{Kkal} / \mathrm{mol} ; 114,24 \mathrm{uM})$, dan (5,46 Kkal/mol; 99,50 uM). Dimana, nilai G; Ki ligan alami dan senyawa standar yaitu (-4,33 Kkal/mol; 667,68 uM) dan (-5,16 Kkal/mol; 166,39 uM).

Prediksi PreADMET (Absorbsi, Distribusi, Metabolisme, Ekskresi dan Analisis toksisitas) penting dalam menilai farmakokinetik molekul kandidat obat. Prediksi absorbsi terdiri dari parameter HIA (Human Intestinal Absorption) dan Caco-2. Parameter (HIA) dapat mengidentifikasi calon obat yang potensial, serta memprediksi rute pemberian dan efektivitasnya (Nunes et al., 2020). Analisis PreADMET mengidentifikasi bahwa dari keempat senyawa uji terbaik $(\mathrm{C} 1$, C2, C3, dan C5) C1 memiliki nilai HIA paling tinggi, yaitu $79,45 \%$ yang berarti dapat dijadikan calon obat oral kare- na mampu diserap dengan baik oleh usus. Parameter Caco2 menunjukkan kemampuan permeabilitas suatu senyawa terhadap epitel usus yang digunakan sebagai model untuk pemilihan calon obat jalur administrasi oral (Nunes et al., 2020). Senyawa yang memiliki nilai Caco-2 tertinggi yaitu senyawa uji 2 dengan nilai $18,30 \mathrm{~nm} / \mathrm{sec}$. Hal tersebut menunjukkan permeabilitas yang baik, dimana, rentang permeabilitas baik yaitu 4-70 nm/sec (Cheng et al., 2013).

Prediksi absorbsi terdiri dari parameter BBB (Blood Brain Barrier) dan PBB (Plasma Protein Binding). BBB adalah penghalang fisiologis yang membatasi perjalanan sebagian besar senyawa dari darah ke otak. Permeabilitas BBB merupakan pertimbangan penting untuk senyawa dengan penargetan SSP (Sistem Saraf Pusat). Distribusi obat tergantung terutama pada pengikatannya dalam darah dengan albumin yang bertanggung jawab untuk menentukan paruh obat. Pengikatan ini menunjukkan nilai PBB. Afinitas suatu senyawa dengan protein plasma menentukan ketersediaan hayati dan membantu menentukan dosisnya. Dengan demikian, lebih kuat obat berikatan dengan protein plasma, maka semakin rendah aksi obat (Nisha et al., 2016). Nilai BBB keempat senyawa terbaik ( $\mathrm{C} 1, \mathrm{C} 2, \mathrm{C} 3$, dan $\mathrm{C} 5)$ berturut-turut yaitu 0,286; 0.035; 0.064; dan 0,0348. Hal ini menunjukkan bahwa hanya $\mathrm{C} 1$ yang memiliki nilai BBB yang baik, sedangkan ketiga senyawa lainnya termasuk rendah. Dimana, rentang kategorinya yaitu 0,1-2,0 (baik) dan <0,1 (rendah).

Metabolisme xenobiotik dilakukan oleh keluarga enzim mikrosomal dikenal sebagai sitokrom P450 (CYP450). CYP450 terdiri dari angka anggota yang terlibat dalam metabolisme obat yang berbeda tetapi dua anggota terpenting 
adalah CYP3A4 dan CYP2D6. Terlepas dari substrat CYP yang ditindaklanjuti oleh enzim ini, Penghambat CYP meningkatkan konsentrasi obat karena hilangnya fungsi enzim. Dengan demikian, memprediksi interaksi ligan dengan enzim CYP450 dapat memberikan gambaran tentang menjadi substrat atau inhibitor atau keduanya (Nisha et al., 2016). Berdasarkan hasil analisis preadmet, keempat senyawa terbaik menjadi inhibitor untuk CYP2C19, CYP2C9, CYP3A4 dan non inhibitor untuk CYP2D6.

Prediksi toksisitas dilakukan dengan melihat parameter ames test. Tes Ames adalah metode sederhana yang memeriksa potensi mutagenik suatu senyawa terhadap strain Salmonella typhimurium (Ames et al., 1972). Dari keempat senyawa terbaik, C1 dan C2 menunjukkan sifat mutagenik, sedangkan C3 dan C5 non mutagenik.

\section{KESIMPULAN}

Senyawa dalam ekstrak daun kenikir (Cosmos caudatus) memiliki potensi inhibitor terhadap IL-6. Berdasarkan hasil docking, didapatkan empat senyawa terbaik, yaitu C1, C2, C3, dan C5. Keempat senyawa tersebut memiliki nilai $\Delta \mathrm{G}$ dan Ki yang lebih baik dibandingkan ligan alami. Hasil PreADMET keempat senyawa tersebut memiliki daya adsorpsi yang baik sehingga dapat dipertimbangkan dalam pembuatan sediaan rute oral. Hasil ames test menunjukkan bahwa $\mathrm{C} 1$ dan $\mathrm{C} 2$ bersifat mutagenik, sedangkan $\mathrm{C} 3$ dan $\mathrm{C} 4$ non mutagenik.

\section{UCAPAN TERIMA KASIH}

Ucapan terima kasih penulis sampaikan kepada Program Studi Farmasi UNPAD dan seluruh pihak yang telah memberikan dukungan dan bantuan dalam penelitian dan penulisan karya tulis ilmiah ini.

\section{Daftar Pustaka}

Ames, B. N., Gurney, E. G., Miller, J. A., Bartsch, H. 1972. Carcinogens as frameshift mutagens: metabolites and derivatives of 2-acetylaminofluorene and other aromatic amine carcinogens. Proceedings of the National Academy of Sciences, 69(11), 3128-3132.

Arwansyah, A., Ambarsari, L., Sumaryada, T. I. 2014. Simulasi docking senyawa kurkumin dan analognya sebagai inhibitor reseptor androgen pada kanker prostat. Current Biochemistry, 1(1), 11-19.

Chen, L., Deng, H., Cui, H., Fang, J., Zuo, Z., Deng, J., Li, Y., Wang, X., Zhao, L. 2017. Inflammatory responses and inflammation-associated diseases in organs. Oncotarget. Vol. 9(6): 7204-7218.

Cheng, J., Palva, A.M., de Vos, W.M., dan Satokari, R. 2013. Contribution of the intestinal microbiota to human health: from birth to 100 years of age. Curr Top Microbiol Immunol. 358: 323-46.

Forlemu, N., Watkins, P., Sloop, J. 2016. Molecular docking of selective binding affinity of sulfonamide derivatives as potential antimalarial agents targeting the glycolytic enzymes: GAPDH, Aldolase and TPI. Open Journal of Biophysics, 7(1), 41-57.

Gabay, C. 2006. Interleukin-6 and chronic inflammation. Arthritis Res Ther. Vol. 8(2): 1-6. Harvard Health Publishing. 2020. Understanding acute and chronic inflammation. Tersedia online di https://www.health.harvard.edu/staying- healthy/understanding-acute-and-chronic-inflammation [Diakses pada tanggal 10 April 2021].

Kopf, M., Baumann, H., Freer, G., Freudenberg, M., Lamers, M., Kishimoto, T., Zinkernagel, R., Bluethmann, H., dan Köhler, G. 2006. Impaired immune and acutephase responses in interleukin-6-deficient mice. Nature. Vol. 368(6469): 339-342.

Mulé, J. J., Custer, M. C., Travis, W. D., dan Rosenberg, S. A. 1992. Cellular mechanisms of the antitumor activity of recombinant IL-6 in mice. J Immunol. Vol. 148(8):2622-2629.

Muttaqin, F.Z., Ismail, H., Muhammad, H.N., 2019. Studi Molecular Docking, Molecular Dynamic, dan Prediksi Toksisitas Senyawa Turunan Alkaloid Naftiridin Sebagai Inhibitor Protein Kasein Kinase 2- pada Kanker Leukimia. Pharmacoscript. Vol 2(2) : 131-151

Nisha, C. M., Kumar, A., Vimal, A., Bai, B. M., Pal, D., Kumar, A. 2016. Docking and ADMET prediction of few GSK-3 inhibitors divulges 6-bromoindirubin-3-oxime as a potential inhibitor. Journal of Molecular Graphics and Modelling, 65, 100-107.

Noviardi, H., Fachrurrazie, F. 2015. Potensi Senyawa Bullatalisin Sebagai Inhibitor Protein Leukotrien A4 Hidrolase Pada Kanker Kolon Secara In Silico. FITOFARMAKA: Jurnal Ilmiah Farmasi, 5(2), 65-73.

Nunes, A. M. V., de Andrade, F. D. C. P., Filgueiras, L. A., de Carvalho Maia, O. A., Cunha, R. L., Rodezno, S. V., Maia, F., Mrtins, L. N. A., Carvalho, A., Mendes, A. N. 2020. preADMET analysis and clinical aspects of dogs treated with the Organotellurium compound RF07: A possible control for canine visceral leishmaniasis?. Environmental Toxicology and Pharmacology, 80, 103470 .

Rahman, H. A., Saari, N., Abas, F., Ismail, A., Mumtaz, W. M., dan Hamid, A. A. 2017. Anti-obesity and antioxidant activities of selected medicinal plants and phytochemical profiling of bioactive compounds. International Journal of Food Properties. Vol. 20(11): 2616-2629.

Sarihati, I. G. A. D., dan Dhyanaputri, I. G. A. S. 2020. Pengaruh Ekstrak Etanol Daun Kenikir (Cosmos caudatus) terhadap Kadar Glutathion Dan Interleukin 6 Serum Tikus Wistar Jantan yang Diberi Pakan Tinggi Kolesterol. Jurnal Kesehatan. Vol. 11(1): 77-85.

Stone, W. L., Basit, H., dan Burns, B. 2020. Pathology, Inflammation. Tersedia online di https:/www.ncbi.nlm.nih.gov/books/NBK534820/ [Diakses pada tanggal 29 Mei 2021] 